\title{
Effects of the Application of Sewage Sludge and Petrochemical Residue in Maize Culture as Source of Micro- nutrients on Soils of Paraná State
}

\author{
Ana T. Jordão Pigozzo, Marlene A. Gobbi, Ervim Lenzi* and Eduardo B. Luchese \\ State University of Maringá, Chemistry Department, Av. Colombo, 5790, CEP 87020-900, Maringá - PR, Brazil.
}

\begin{abstract}
An evaluation of the potential of two organic residues as source of micro-nutrients in three soils of Paraná state was studied. Treatments consisted of one dose $\left(38 \mathrm{t} . \mathrm{ha}^{-1}\right)$ of sewage sludge and residue of purified used motor oil both neutralized with $\mathrm{CaO}+\mathrm{MgO}$ mixture in 3:1 rate. Maize (Zea mays L.) was used as reference plant. After 30 days of seeding, the aerial parts of the plants were cut. They were dried at $70^{\circ} \mathrm{C}$ till constant weight and ground. Analysis was undertaken after nitric-perchloric digestion. Micro-nutrients levels in the soils and in the aerial parts of the plants were determined by atomic absorption spectrometry. The results showed a production of the aerial parts of the plants treated with sewage sludge higher than those in other treatments. The micro-nutrients in Terra Roxa - TR were higher than those of Latossolo Vervelho Escuro - LE (Deep Red Latisol) and Podzólico Vermelho - PV (Red Podzolic) soils, respectively. In the aerial part of the maize plants in treated soils concentrations of micro-nutrients $\mathrm{Cu}, \mathrm{Fe}, \mathrm{Mn}$ and $\mathrm{Zn}$ were higher than those without treatment.
\end{abstract}

Key words: Sewage sludge, oil residue, environmental pollution, micro-nutrients

\section{INTRODUCTION}

Human activity produces great quantities of refuse, called urban residue or trash (Lima, 1985). In the great majority of cases, refuse has high levels of organic matter which may be transformed into organic fertilisers (IPT, 1995). The type of refuse common to urban agglomerations is the home sewage which is frequently disposed of in the environment without any treatment. It pollutes water resources and endangers quality of life (Przybysz \& Guidi, 1997). When sewage is treated, it creates an organic residue called sewage sludge for which a suitable destination should be found (Manahan, 1994).

Use of sewage sludge in agriculture has been a constant and well-accepted practice (Favaretto et al., 1997 and McBride, 1995). Dependent on its composition, sewage sludge in agriculture may represent a source of nutrients, betterment of soil conditions due to its high level of organic matter, a solution to the storage problem due to the great quantity produced especially in urban agglomerations (De Deus, 1992). The feasibility to use it in soils appropriate for culture not directly destined for food is very promising. There is, however, concern about the presence of heavy metals and pathogenic germs (Bertoncini, 1997 and Andreoli \& Fernandes, 1997).

Another type of human refuse of an industrial nature and organic composition is residue of used motor oil or lubricants (petrochemical residues). In Brazil, some $400,000 \mathrm{~m}^{3}$ of used lubricants, of engine and industrial origin, are discarded annually (Araújo, 1992). Residue of used motor oil is of organic nature and has high levels of sulphuric acid as a consequence of the refinery process. Residue is acid waste and amounts to about $15 \%$ of volume of oil used in the re-refinery process. At present, this residue is discarded in lakes without any previous treatment and constitutes a source of pollution in the environment. Residue contains organic matter and metal remains from the wear and tear of engines (Fe, $\mathrm{Cu}, \mathrm{Mn}, \mathrm{Zn}$ and others) which may be useful for the bettering of soil fertility.

When applied to soil, organic material of refuse needs mineralization so that beneficent effects on soil fertility may be obtained. Temperature, humidity, aeration, $\mathrm{pH}$, nutrient level are some

\footnotetext{
* Author for correspondence
} 
variables that control the microbiological activity of mineralization (Ladonin \& Margolina, 1997; Cavallaro et al., 1993; Sarkis, 1987; Bull, 1986).

Availability of metallic ions, including nutrients, in soil solution depends on a series of factors, texture and clay composition of the soil, competition by other cations for absorption sites. (Hooda \& Alloway, 1996; Smith, 1994; Zhu \& Alva, 1993; Sposito, 1989; Oates \& Coldwel, 1985; Pavan et al., 1984; Jardim, 1983). Absorption of metal ions by plants depends on the availability of the same in soil solution and on characteristics proper to each species in its different stage of development (Farina et al., 1980; Epstein, 1975).

In applications of sewage sludge and petrochemical residues it has been observed that the production of the aerial part of plants cultivated is associated to the relationship Ca:Mg and C:N of soil (EMBRAPA, 1983; Farina et al., 1980; Silva, 1980). Maize (Ros et al., 1990; Silva, 1980), rice and tomatoes (Hosono et al., 1979), lettuce (Hernandez et al., 1992) and sugar cane (Silva, 1995) are among the species tested in soils treated with sewage sludge.

For the establishment of criteria, studies at international (McBride, 1995), national (MatiazzoPrezotto, 1994) and Paraná state (Andreoli et al., 1997) levels were undertaken for possible environment impacts caused by sludge application to soils.

Because of the variation in the composition of sewage sludge and because of the scanty studies on a thoroughly secure destination for petrochemical residues, the matter is worthy of attention. However, new experiments must be conducted for better technical and scientific clarifications. The present research work evaluates the effect of sewage sludge and petrochemical residue neutralized by $\mathrm{CaO}+\mathrm{MgO}$ (3:1) applied to Terra Roxa - TR, Latossolo Vermelho Escuro LE (Deep Red Latisol - DRL) and Podzólico Vermelho - PV (Red Podzolic - RP) soils in the development of maize.

\section{MATERIALS AND METHODS}

Characterization of soils, sludge and petrochemical residue: Soils used in experiment were collected in the region of Maringá, PR, Brazil from horizon A, depth $0-20 \mathrm{~cm}$, belonging to different classes of texture. They were classified as Terra Roxa - TR a clayey soil, Latossolo Vermelho Escuro - LE (Deep Red Latisol - DRL) a medium texture soil and Podzólico Vermelho PV (Podzolic Red - PR) a sandy soil. Samples were dried in a clean and ventilated place air, and sifted in a $2 \mathrm{~mm}$ sieve. The percentage of base saturation was raised at $70 \%$ with calcite limestone.

Sewage sludge used was obtained from Sewage Treatment Station in Curitiba, PR, Brazil. It was neutralized with $60 \%$ (dry weight) of a mixture of $\mathrm{CaO}+\mathrm{MgO}$ in the proportion of $3: 1$ to avoid undesired smells and germs proliferation, especially pathogenic ones. For incorporation to soils it was then dried, ground and homogenized.

Petrochemical residue was obtained from industrial processing of lubricant oil recuperation of Nortoil Ltd of Maringá, PR, Brazil. Neutralization of residue was identical to that used in sludge to avoid high acidity from refining process.

Chemical characterization of sewage sludge and of plugged petrochemical residue was undertaken. $\mathrm{Cu}, \mathrm{Fe}, \mathrm{Zn}$ and $\mathrm{Mn}$ were determined by atomic absorption spectrometry, flame technique, after nitric-perchloric digestion of samples (Griepink, 1984). Elemental $\mathrm{C}$ and $\mathrm{N}$ were dosed with classical methods of gravimetry and Kjeldahl respectively (Horwitz, 1980).

Experiment assembly and collection of samples: Collected soils (2 liters per vase) received a dose of petrochemical residue and sewage sludge equivalent to 38 t.ha $^{-1}$ ( $47.50 \mathrm{~g}$ per vase). Threeliter polyethylene vases were used. Experiment was conducted in a green house with three repetitions and each vase received water up to $70 \%$ to its capacity. Systems (soil+sludge and soil+petrochemical residue) were incubated for 15 days. 5 seeds of hybrid maize, cultivar BR, were planted. After germination plant pruning was undertaken and three plants were left in each vase. After thirty days of seeding, harvest of the upper part of the maize plant was done. Samples were dried and the respective level of dry matter per vase was determined. They were then ground, dried once again and stored for further analysis. After the harvest of the plant's upper part, contents of vases with rhizome (stalk and roots) and soil were placed on a plastic sheet and stalk was removed. After dried in an aerated and clean place, soil from each vase was sifted in 2-mm sieve and stored for further analysis. 
Analysis of dry matter from the upper part of the maize stalk: Exact portions $(0.2000 \mathrm{~g})$ were weighed in triplicates of each sample of plant's upper part. The sample digestion was made by the nitric perchloric mixture (Horwitz, 1980). Concentrations of elements $\mathrm{Cu}, \mathrm{Fe}, \mathrm{Zn}$ and $\mathrm{Mn}$ were read by atomic absorption spectrometric technique (atomic absorption spectrometer, Varian model - Spectr AA 10 Plus) (Welz, 1985). Reference and standards for each element underwent the same digestion process of their respective samples. Nitrogen level was determined by Kjeldhal classical method and carbon by gravimetric method of mass loss to deep red (Horwitz, 1980).

Analysis of residual soil and of experimental data: Analysis of samples of residual soil followed same technique as those employed in chemical characterisation of virgin soils. $\mathrm{Cu}, \mathrm{Fe}, \mathrm{Zn}$ and $\mathrm{Mn}$ were extracted by extractor Mehlich. Concentration of these ions was determined by atomic absorption technique. Nitrogen and carbon were analysed by methods employed in analysis of maize dry matter. Potential acidity $\left\{\left[\mathrm{H}^{+}\right]+\left[\mathrm{Al}^{3+}\right]\right\}$ in $\mathrm{cmol}_{\mathrm{c}} \cdot \mathrm{kg}^{-1}$ was determined by the method of calcium acetate solution.

Experiment data were submitted to variance analysis employing Tukey's method to interpret differences at $5 \%$ level of significance (SANEST).

\section{RESULTS AND DISCUSSION}

Soils and Treatments: According to data in Table 2, 4,513 and 6,085 of C; 3,132 and 290 of $\mathrm{N} ; 5.65$ and 3.42 of $\mathrm{Cu} ; 15.6$ and 63.7 of $\mathrm{Zn} ; 117$ and 368 of Fe; 10.7 and 6.89 of Mn, respectively, were added to soils in each vase, in mg.vase ${ }^{-1}$, via neutralized sewage sludge and petrochemical residues.

Table 1. Chemical characteristics of soils in experiment*

\begin{tabular}{lccccccccccc}
\hline Soil & $\mathrm{C}$ & $\mathrm{N}$ & $\mathrm{Cu}^{\mathrm{a}}$ & $\mathrm{Fe}^{\mathrm{a}}$ & $\mathrm{Mn}^{\mathrm{a}}$ & $\mathrm{Zn}^{\mathrm{a}}$ & $\mathrm{H}^{+}+\mathrm{Al}^{3+}$ & $\begin{array}{c}\mathrm{CEC} * * \\
\mathrm{BS} *\end{array}$ & $\begin{array}{c}\mathrm{C}: \mathrm{N} \\
\mathrm{Ca}: \mathrm{Mg}^{* *} \\
(\%)\end{array}$ & $\begin{array}{c}\leftarrow-- \\
\text { relation--- } \rightarrow\end{array}$ \\
\hline TR & 12 & 1.3 & 5.0 & 180 & 195 & 3.4 & 2.3 & 6.8 & 66.0 & $9: 1$ & $3: 1$ \\
LE (DRL) & 10 & 0.60 & 3.0 & 165 & 50.0 & 1.8 & 1.3 & 4.4 & 70.0 & $17: 1$ & $3: 1$ \\
PV (RP) & 8.0 & 0.60 & 2.5 & 86.0 & 44.0 & 1.2 & 1.0 & 3.7 & 72.0 & $13: 1$ & $2: 1$ \\
\hline
\end{tabular}

TR - Terra Roxa; LE - Latossolo Vermelho Escuro (DRL - Deep Red Latisol); PV - Podzólico Vermelho (RP Red Podzolic); a - nutrient extracted by Mehlich extractor; $\left[\mathrm{H}^{+}+\mathrm{Al}^{3+}\right]$ - potential acidity; CEC - Cationic Exchange Capacity; BS = Base Saturation; * - values correspond to averages of analyses results in triplicates; ** - data from Gobbi (1998).

Table 2. Chemical Characteristics of sewage sludge and petrochemical residue in experiment

\begin{tabular}{|c|c|c|c|c|c|c|c|}
\hline \multirow[t]{2}{*}{ Residues } & $\mathrm{Cu}$ & $\overline{Z n}$ & $\mathrm{Fe}$ & $\mathrm{Mn}$ & $\mathrm{C}$ & $\overline{\mathrm{N}}$ & \multirow{2}{*}{$\begin{array}{c}\mathrm{C} / \mathrm{N} \\
\text { relation }\end{array}$} \\
\hline & \multicolumn{4}{|c|}{$\leftarrow$} & \multicolumn{2}{|c|}{$\leftarrow--$ g. $\mathrm{kg}^{-1}---\rightarrow$} & \\
\hline Curitiba Sewage Sludge (CSS 60\%) & 119.0 & 328.0 & 2462.0 & 225.0 & 95.0 & 6.6 & 14:1 \\
\hline Used Oil Residues (UOR 60\%) & 72.0 & 1340.0 & 7750.0 & 145.0 & 128 & 6.1 & 21:1 \\
\hline
\end{tabular}

Values correspond to averages of analyses results in triplicates; relation $\mathrm{C}: \mathrm{N}$ was approximated.

Results of chemical analyses of soils with and without treatment after 45 days are shown in Table 5. It may be perceived that there was a significant increase in $\mathrm{Cu}, \mathrm{Fe}, \mathrm{Zn}$ and $\mathrm{Mn}$ levels available in soils treated with neutralized petrochemical residues and sewage sludge compared to those in reference.

In Table 5 the $\mathrm{pH}$ influence in availability of micro-nutrients under study may be observed. Soils without treatment (reference) made $\mathrm{Cu}, \mathrm{Fe}$, $\mathrm{Mn}$ and $\mathrm{Zn}$ available in the order TR $>$ LE (DRL) $>\mathrm{PV}(\mathrm{RP})$ with $\mathrm{pH}$ 6.0, 5.6 and 7.0 respectively.
Availability of micro-nutrients in treated soils continued in the same order. In Terra Roxa (TR), however, their availability was proportionally greater than in the others, probably due to more favourable $\mathrm{pH}$, or rather, lower $\mathrm{pH}, \mathrm{TR}+\mathrm{SS}(\mathrm{pH}=$ 7.9) and $\mathrm{TR}+\mathrm{PR}(\mathrm{pH}=7.8)$. Lowering of $\mathrm{pH}$ level favours solubility of the micro-nutrients. For instance, variation of a $\mathrm{pH}$ unit varies copper concentration a hundred times (Tisdale et al., 1985). Interrelationship of copper levels available in soil solution in the order TR : LE (DRL) : PV (RP) produced the following result: without 
treatment: (1:2:4); with petrochemical residue treatment (1:1:5); with sewage sludge treatment (1:1:7). $\mathrm{Fe}$ and $\mathrm{Zn}$ were less sensitive to favourable variation of $\mathrm{pH}$. Rather, with $\mathrm{pH}$ elevation from 7.8 to 8.6 interval in treatment, trend was for the non-availability of these micronutrients, even to the point of their total absence (Jordão-Pigozzo, 1998; Hooda \& Alloway, 1996; Novais et al., 1987; Bull \& Cantarella, 1993; Flores et al., 1979; Lindsay, 1979).

Table 3. Production of dry matter, in g.vase ${ }^{-1}$, in maize plants, cultivated in three soils with and without treatment of sewage sludge and petrochemical residues, after 30 days of germination.*

\begin{tabular}{lccc}
\hline Treatment & \multicolumn{3}{c}{ Soils } \\
\cline { 2 - 4 } & TR & LE (DRL) & PV (RP) \\
\hline Soil + Sludge & $4.82^{\mathrm{a}}$ & $4.71^{\mathrm{a}}$ & $4.43^{\mathrm{a}}$ \\
Soil + Petrochemical Residue & $3.00^{\mathrm{c}}$ & $2.15^{\mathrm{b}}$ & $2.00^{\mathrm{b}}$ \\
Reference & $3.94^{\mathrm{b}}$ & $2.59^{\mathrm{b}}$ & $1.92^{\mathrm{b}}$ \\
\hline
\end{tabular}

* - Values correspond to average of plants in three vases respectively; Averages followed by same letter (a,b, ...) do not differ among themselves at 5\% level of significance by Tukey's test; TR - Terra Roxa; LE - Latossolo Vermelho Escuro (DRL Deep Red Latisol); PV - Podzólico Vermelho (RP - Red Podzolic).

Table 4. Accumulated quantity of $\mathrm{Cu}, \mathrm{Fe}, \mathrm{Zn}$ and $\mathrm{Mn}$ in $\mathrm{mg} \cdot \mathrm{kg}^{-1}$, in upper part of maize plant, in three soils, with and without treatment.*

\begin{tabular}{|c|c|c|c|c|c|c|c|c|c|}
\hline \multirow[t]{2}{*}{ Elements } & \multicolumn{3}{|c|}{ Soil with sewage sludge } & \multicolumn{3}{|c|}{ Soil with petrochemical residue } & \multicolumn{3}{|c|}{$\begin{array}{c}\text { Soil without treatment } \\
\text { (reference) }\end{array}$} \\
\hline & TR & LE (DRL) & $\mathrm{PV}(\mathrm{RP})$ & TR & LE (DRL) & $\mathrm{PV}(\mathrm{RP})$ & TR & LE (DRL) & $\mathrm{PV}(\mathrm{RP})$ \\
\hline $\mathrm{Cu}$ & 11.7 & 7.5 & 7.5 & 8.6 & 7.0 & 6.8 & 7.5 & 6.5 & 5.0 \\
\hline $\mathrm{Fe}$ & 197.0 & 218.0 & 215.0 & 202.0 & 230.0 & 225.0 & 95.0 & 92.0 & 85.0 \\
\hline $\mathrm{Mn}$ & 53.0 & 38.0 & 36.0 & 40.0 & 36.0 & 33.0 & 40.0 & 33.0 & 28.0 \\
\hline $\mathrm{Zn}$ & 53.6 & 56.2 & 58.4 & 63.4 & 79.9 & 80.6 & 38.0 & 35.0 & 35.0 \\
\hline
\end{tabular}

TR - Terra Roxa; LE - Latossolo Vermelho Escuro (DRL - Deep Red Latisol); PV - Podzólico Vermelho (RP - Red Podzolic); * - values correspond to average of analyses in triplicate.

Table 5. Chemical characteristics of soils after harvest of maize plants and after 45 days of incubation with and without treatment.*

\begin{tabular}{|c|c|c|c|c|c|c|c|c|c|}
\hline \multirow[t]{2}{*}{ Soil } & \multirow{2}{*}{$\begin{array}{c}\mathrm{pH} \\
\mathrm{CaCl}_{2}\end{array}$} & $\mathrm{C}$ & $\mathrm{N}$ & $\mathrm{Cu}$ & $\mathrm{Fe}$ & $\mathrm{Mn}$ & $\mathrm{Zn}$ & $\mathrm{Ca}: \mathrm{Mg}^{* *}$ & $\mathrm{C}: \mathrm{N}$ \\
\hline & & $\leftarrow-$ & $--\rightarrow$ & \multicolumn{4}{|c|}{ 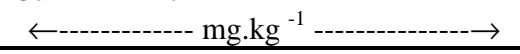 } & \multicolumn{2}{|c|}{$\leftarrow---$ Relation---- $\rightarrow$} \\
\hline $\mathrm{TR}+\mathrm{SS}$ & 7.9 & 17 & 1.3 & 24.8 & 218.0 & 216.0 & 23.1 & $31: 1$ & $13: 1$ \\
\hline $\mathrm{LE}(\mathrm{DRL})+\mathrm{SS}$ & 8.2 & 12 & 0.9 & 3.8 & 201.0 & 50.8 & 14.1 & $23: 1$ & $13: 1$ \\
\hline$P V(R P)+S S$ & 8.3 & 12 & 0.8 & 3.5 & 170.0 & 48.5 & 10.9 & $15: 1$ & $15: 1$ \\
\hline $\mathrm{TR}+\mathrm{PR}$ & 7.8 & 17 & 1.0 & 14.4 & 236.0 & 202.0 & 37.4 & $27: 1$ & $17: 1$ \\
\hline $\mathrm{LE}(\mathrm{DRL})+\mathrm{PR}$ & 8.3 & 11 & 0.6 & 3.6 & 222.0 & 48.2 & 25.6 & $27: 1$ & $18: 1$ \\
\hline$P V(R P)+P R$ & 8.6 & 10 & 0.7 & 3.0 & 183.4 & 40.0 & 21.8 & 18:1 & $14: 1$ \\
\hline TR & 6.0 & 9.0 & 0.9 & 4.7 & 148.0 & 182.0 & 3.0 & $3: 1$ & $10: 1$ \\
\hline LE (DRL) & 5.6 & 9.0 & 0.6 & 2.5 & 125.0 & 40.0 & 1.2 & $4: 1$ & $15: 1$ \\
\hline PV (RP) & 7.0 & 8.0 & 0.6 & 1.2 & 65.0 & 38.0 & 1.0 & $2: 1$ & $13: 1$ \\
\hline
\end{tabular}

TR - Terra Roxa; LE - Latossolo Vermelho Escuro (DRL - Deep Red Latisol); PV - Podzólico Vermelho (RP Red Podzolic); SS.- Sewage sludge; PR - Neutralized Petrochemical Residue. * - Values are averages of results from analyses in triplicate; ** - Data from Gobbi (1998).

An approximate balance of mass for $\mathrm{N}$ and $\mathrm{C}$ employing data of Tables 1 and 2 for different soils and a comparison with what remained of them after 45 days of incubation and maize planting, Table 5, verify that in this period there was no mineralization of organic material associated to $\mathrm{N}$ and $\mathrm{C}$. If there were, it would be insignificant (Zibilske, 1987). In some instances there was a slight increase of $\mathrm{C}$ which must be due to possible remnants of little roots left over during the process of freeing the lower stalk from the soil. 
Treatments with petrochemical residues with greater $\mathrm{Zn}$ concentrations didn't make element more available for plants. This fact shows low mineralization of residue and $\mathrm{pH}$ influence.

Maize plants: Harvest of maize plants was undertaken on the $30^{\text {th }}$ day after seeding since plants with sewage sludge treatment and neutralized petrochemical residues presented signs of senescence by their yellow color and dry tips of leaves. Probably this was due to excess of salinity caused by addition of neutralized residues with high quantities of $\mathrm{CaO}$. Salinity was visually detected by salts at the surface of treated soils. Water absorption by plants become difficult due to an increase in osmotic pressure of soil solution. Plants with reference treatment showed no such occurrence (Cripps \& Matocha, 1991, Cramer et al., 1987).

Weight results of dry matter (upper part of stalk) of maize plants with and without treatment with neutralized residues are found in Table 3. In all soils, production of dry matter was greater in treated soils with neutralized sewage sludge; this was followed by reference treatment; however, they differed statistically between themselves and with neutralized petrochemical residue treatment. In the latter case, production of dry matter was lower than reference treatment. Thus, under the conditions materials were incorporated to soils and during the time of the experiment, it is advisable that the material produced by petrochemical residues would not be used as soil fertilizer. It has also been found that the matter produced by sewage sludge yielded better conditions for soil fertility with regard to the development of the maize plants. For both soils, with and without treatment, production of dry matter follows pattern TR > LE (DRL) > PV (RP), equivalent to the availability of nutrients in soil.

Depressive effect in yield seems to be also related to nutritional disturbances in plants induced by unfavourable cationic relationships in soil. Absorption of nutrients by plants depends on ion activities in the solution and in exchange sites (Rosolem et al., 1984).

Plants absorbed more copper and manganese in the following soil order: TR > LE (DRL) > PV (RP) and in the following order of treatments: with sludge > with petrochemical residue > without treatment (Table 4). This didn't occur with iron and zinc. As perceived previously, results reflected respective behaviors of their availability in soils.
Average copper concentrations in plants harvested in soils with and without treatment are in the interval $5.0-11.7 \mathrm{mg} . \mathrm{kg}^{-1}$. These values are within interval 5.0-30 mg. $\mathrm{kg}^{-1}$, considered normal or sufficient (Kabata-Pendias \& Pendias, 1992 and Malavolta et al., 1997).

Average iron concentrations in plants harvested in soils with and without treatments are within interval $85-230 \mathrm{mg} \cdot \mathrm{kg}^{-1}$. These values are within interval 50-250 mg.kg ${ }^{-1}$, considered normal (Malavolta et al., 1997).

The same analysis is repeated in the case of manganese and zinc with respective normal intervals as follows: $30-300$ and $27-150 \mathrm{mg} \cdot \mathrm{kg}^{-1}$ (Kabata-Pendias \& Pendias, 1992). Results for Mn suggest that quantity of nutrients added to soils via residues is small when compared to the great quantities soils present in their natural state. Leave levels of $\mathrm{Mn}$, generally considered adequate for maize, were $150 \mathrm{mg} \cdot \mathrm{kg}^{-1}$ (Malavolta et al., 1997). Increase in $\mathrm{Zn}$ level in plant tissue didn't result in an increase of dry matter weight. Monteiro (1991) informs that experimental data in different places with forage grass in different types of soils showed small or no alteration in the production of dry matter in plants with the inclusion of micronutrient fertilizing, $\mathrm{Zn}$ among them.

Concentration levels of these nutrients in plants never reached phytotoxic levels (Kabata-Pendias \& Pendias, 1992). On the contrary, intervals of values are placed closer to lowest limit of intervals considered normal.

\section{CONCLUSIONS}

Conclusions from above results are:

1. Although plants in treated soils showed signs of senescence, treatment with neutralized sewage sludge yielded higher production of dry matter than others. When treated with petrochemical residues production of dry matter was lower than that of reference.

2. Application of neutralized residues with high concentrations of $\mathrm{CaO}$ gave higher $\mathrm{pH}$ values in soils.

3. Different residues incorporated to soils showed potentiality as micronutrient source.

4. Assimilation of micronutrients in the plant's upper part was adequate for maize culture.

5. Taking into consideration the type of soil TR > LE $($ DRL) $>$ PV (RP), decreasing order in the 
production of dry matter was the same for soils with and without treatment.

\section{RESUMO}

Em casa de vegetação avaliou-se a potencialidade de dois resíduos orgânicos como fonte de micronutrientes em três solos do Estado do Paraná. Os tratamentos consistiram de uma dose $\left(38\right.$ t.ha $\left.^{-1}\right)$ de resíduo petroquímico e de lodo de esgoto neutralizados. O milho safrinha (Zea mays $L$.) foi utilizado como planta teste. Após 30 dias da semeadura, cortou-se a parte aérea das plantas. Estas foram secadas a $70^{\circ} \mathrm{C}$, até se obter peso constante, moídas e analisadas após a digestão nitro-perclórica. Os teores de micronutrientes nos solos e nas plantas foram determinados por espectrometria de absorção atômica. Os resultados mostraram que a produção de material seco foi superior com o lodo de esgoto. Os teores de micronutrientes no solo TR (Terra Roxa) foram superiores aos dos solos LE (Latossolo Vermelho Escuro) e PV (Podzólico Vermelho), respectivamente. Na parte aérea das plantas de milho dos solos tratados as concentrações dos elementos $\mathrm{Cu}, \mathrm{Mn}, \mathrm{Fe}, \mathrm{Zn}$ foram maiores que as do solo testemunha, com exceção do Mn no solo PV.

\section{REFERENCES}

Andreoli, C. V.; Fernandes, F. (1997), Principais fatores limitantes (metais pesados e patógenos) para o uso agrícola do lodo de esgotos no Paraná. Sanare, 7(7), 68-72.

Andreoli, C.V.; Bonnet, B.R.P.; Lara, A. I.; Wolter, F.R. (1997), Proposição de plano de monitoramento da reciclagem agrícola do lodo de esgoto no Estado do Paraná. Sanare, 7(7), 76-84.

Araujo, M.A.S. (1992), Re-refino de óleos usados. Centro de Pesquisa e Desenvolvimento Leopoldo A.M. de Mello. Divisão de Tecnologia de Produtos, Programa CONPET, Petrobrás, Rio de Janeiro, pp. $1-5$.

Bertoncini, E.I. (1997), Mobilidade de metais pesados em solos tratados com lodo de esgoto. Dissertação de Mestrado, USP, Piracicaba, São Paulo, Brasil.

Bull, L.T.; Cantarella, H. (1993), Cultura do milho fatores que afetam a produtividade. Potafos, Piracicaba, $301 \mathrm{pp}$.

Bull, L.T. (1986), Influência da relação $K /(C a+M g)$ do solo na produção de matéria seca e na absorção de potássio por gramínea e leguminosa forrageira.
Tese de Doutorado, USP, Piracicaba, São Paulo, Brasil.

Cavallaro, N.; Padilla, N.; Villarrubia, J. (1993), Sewage sludge effects on chemical properties of soils. Soil Sci., 156(2), 62-70.

Cramer, G.R.; Laughli, A.; Epstein, E. (1987), Calcium salinity interactions in plants. J. Plant Nutr., 10, 9-16.

Cripps, R.W.; Matocha, J.E. (1991), Effects of sewage application to ameliorate iron deficiency of grain sorghum. Comm. Soil Sci. Plant Anal., 22, 19311940.

De Deus, A.B.S. (1992), Avaliação sanitária $e$ ambiental de lodos de ETEs. Dissertação de Mestrado, Engenharia de Recursos Hídricos e Saneamento Ambiental, UFRS, Porto Alegre (RS), Brasil.

EMBRAPA (Empresa Brasileira de Pesquisa Agropecuária) (1983), Cultura do milho. Centro Nacional de Pesquisa do Milho e do Sorgo, Brasília, $85 \mathrm{pp}$.

Epstein, E. (1975), Nutrição mineral das plantas: princípios e perspectivas. EDUSP, São Paulo, 341 pp.

Farina, M.P.W.; Summer, M.E.; Plank, C.O.; Letzch, W.S. (1980), Effect of $\mathrm{pH}$ on soil magnesium and its absorption by corn. Comm. Soil Sci. Plant Anal., 11(10), 981-992.

Favaretto, N.; Deschamps, C.; Daros, E.; Pissaia, A. (1997), Efeito do lodo de esgoto na fertilidade do solo e no crescimento e produtividade de milho (Zea mays L). Braz. Arch. Biol. Tecnol., 40(4), 837-848.

Flores, R.A.; Bornemisza, E.; Alvarado, A. (1979), Influência de las propriedades de suelos del Pacifico Sur sobre su contenido de cationes menores. Il cobre y zinco extraíbles. Turrialba,. 29, 105-110.

Gobbi, M.A. (1998), Avaliação da potencialidade de diferentes resíduos como fonte de macronutrientes na cultura do milho (Zea mays L). Dissertação de Mestrado, Departamento de Química, Universidade Estadual de Maringá, Maringá, Paraná, Brasil.

Griepink, B. Muntau, H. and Colinet, E. (1984), Certification of the content of some heavy metals $(\mathrm{Cd}, \mathrm{Co}, \mathrm{Cu}, \mathrm{Mn}, \mathrm{Hg}, \mathrm{Ni}, \mathrm{Pb}$ and $\mathrm{Zn}$ ) in three types of sewage sludge. Fresenius Z. Anal. Chem. 318:490494.

Hernandez, T.; Garcia, C.; Costa, F.; Valero, J.A.; Ayuso, M. (1992), Utilización de resíduos urbanos como fertilizantes orgánicos. Suelo y Planta, 2(3), 373-83.

Hooda, P.S.; Alloway, B.J. (1996), The effect of liming on heavy metal concentrations in wheat, carrots and spinach grown on previously sludge applied soils. $J$. Agr. Sci., 127, 289-294.

Horwitz, W. [Editor] (1980), Official Methods of Analysis of the Association of Official Analytical Chemists. 13. ed. Association of Official Analytical Chemists - AOAC, Washington, 1018 pp. 
Hosono, M.; Rii, P.; Tachibana, Y.; Ohta, Y. (1979), Alleviation by heavy metal toxicities in crop plants (II) Effects of calcium concentration in nutrient solutions on heavy metal accumulation in rice and tomato plants. J. Sci. Manure, 50, 358-360.

IPT - (Instituto de Pesquisas Tecnológicas) (1995), Lixo municipal - Manual de gerenciamento integrado. Instituto de Pesquisas Tecnológicas de São Paulo, São Paulo, 278 pp.

Jardim, W.F. (1983), Metais pesados: um dano irreparável. Rev. Bras. Tecnol., 14, 41-45.

Jordão-Pigozzo, A.T. (1998), Avaliação da potencialidade de diferentes resíduos como fonte de micronutrientes na cultura do milho (Zea mays L.). Dissertação de Mestrado, Departamento de Química, Universidade Estadual de Maringá, Maringá (PR), Brasil.

Kabata-Pendias, A. ; Pendias, H. (1992), Trace elements in soils and plants. 2. Ed. CRC Press, Boca Raton (USA), 365 pp.

Ladonin, D.V.; Margolina, S.E. (1997), Interaction between humic acids and heavy metals. Euras. Soil Sci., 30, 710-1715.

Lima, L. M. Q. (1985), Tratamento do lixo. HEMUS Editora Ltda., São Paulo, pp. 09-15.

Lindsay, W.L. (1979), Chemical equilibria in soils. John Wiley \& Sons, New York, 449 pp.

Malavolta, E.; Vitti, G.C.; Oliveira, S.A. de. (1997), Avaliação do estado nutricional das plantas. 2. ed. Potafos, Piracicaba, 319 pp.

Manahan, S.E. (1994), Environmental chemistry. 4. ed. Lewis Publishers, Chelsea (USA), 612 pp.

Mattiazzo-Prezotto, M.E. (1994), Comportamento do cobre, cádmio, cromo, níquel e zinco adicionados a solos de clima tropical em diferentes valores de $\mathrm{pH}$. Livre Docência, USP, Piracicaba, São Paulo, Brasil.

McBride, M. B. (1995), Environmental Issues. J. Qual., 24, $5-18$.

Monteiro, F.A. Forrageiras. (1991), In: Ferreira, M.E. \& Cruz, M.C.P. Micronutrientes na agricultura. Piracicaba: POTAFOS/CNPq, pp. 651-682.

Novais, R.F.; Neves, J.C.L.; Barros, N.F.; Sediyama, T. (1987), Deficiência de manganês em soja cultivada em solo de cerrado. In: $21^{\circ}$ CONGRESSO BRASILEIRO DE CIÊNCIA DO SOLO, Campinas. Sociedade Brasileira de Ciência do Solo, Resumos, pp. 177-178.

Oates, K.M. ; Coldwel, G. (1985), Use of by product gypsum to alleviate soil acidity. Soil Sci. Soc. Am. J., 49, 915-918.

Pavan, M.A.; Bingham, F.T.; Patt, P.F. (1984), Redistribution of exchangeable calcium, magnesium and aluminum following lime or gypsum applications to a Brazilian soil. Soil Sci. Soc. Am. J., 48, 33-38.

Przybysz, L.C.B.; Guidi, E.F. (1997), Uso adequado dos sistemas de coleta e tratamento de esgotos domésticos - enfoque ambiental. Sanare, 7(7), 20-23.

Ros, C.A.C da; Aita, C.; Ceretta, C.A.; Fries, M.R. (1990), Utilização do lodo de esgoto como fertilizante: efeito imediato no milho e residual na associação de aveia + ervilha. In: REUNIÃO BRASILEIRA DE FERTILIZANTES DO SOLO E NUTRIÇÃO DE PLANTAS, Santa Maria, 1990. Livro de Resumos, pp. 20.

Rosolem, C.A.; Machado, J.K.; Brinholi, O. (1984), Efeito das relações $\mathrm{Ca} / \mathrm{Mg}, \mathrm{Ca} / \mathrm{K}$ e $\mathrm{Mg} / \mathrm{K}$ do solo na produção de sorgo sacarino. Pesq. Agrop. Bras., 19(12), 1443-1448.

Sarkis, K. (1987), Evaluating land application effects Results on Philadelphia sludge application program on corn and soybean fields provide useful data on heavy metal and PCB accumulation. Biocycle, 28(1), 27-28.

Silva FF.C. (1995), Uso agronômico do lodo de esgoto: efeito em fertilidade do solo e qualidade da cana de açúcar. Tese do Doutorado, USP, Piracicaba, São Paulo, Brasil.

Silva, J.E. (1980), Balanço do cálcio e magnésio e desenvolvimento de milho em solos sob cerrado. Pesq. Agrop. Bras., 15(3), 329-333.

Smith, S.R. (1994), Effects of soil pH on availability to crops of metals in sewage treated soils: Nickel, Cooper and Zinc uptake and toxicity to ryegrass. Environ. Pollut., 85, 321-327.

Sposito, G. (1989), The chemistry of soils. Oxford University Press, New York, 277 pp.

Tisdale, S.L.; NELSON, W.L.; BEATON, J.D. (1985), Soil fertility and fertilizers. 4. ed. McMillan Publishing Company, New York, 754 pp.

Welz, B. (1985), Atomic absorption spectrometry. 2. ed. VCH Verlagsgesellschaft $\mathrm{mbH}$, Weinheim (Germany), 506 pp.

Zhu, B.; Alva, A.K. (1993), Trace metal and cation transport in a sandy soil with various amendments. Soil Sci. Soc. Am. J., 57, 723-727.

Zibilske, L.M. (1987), Dynamics of nitrogen and carbon in soil during paper mill sludge decomposition. Soil Sci., 143(1), 26-33.

Received: September 17, 1998; Revised: November 23,1998; Accepted: November 12, 1999. 